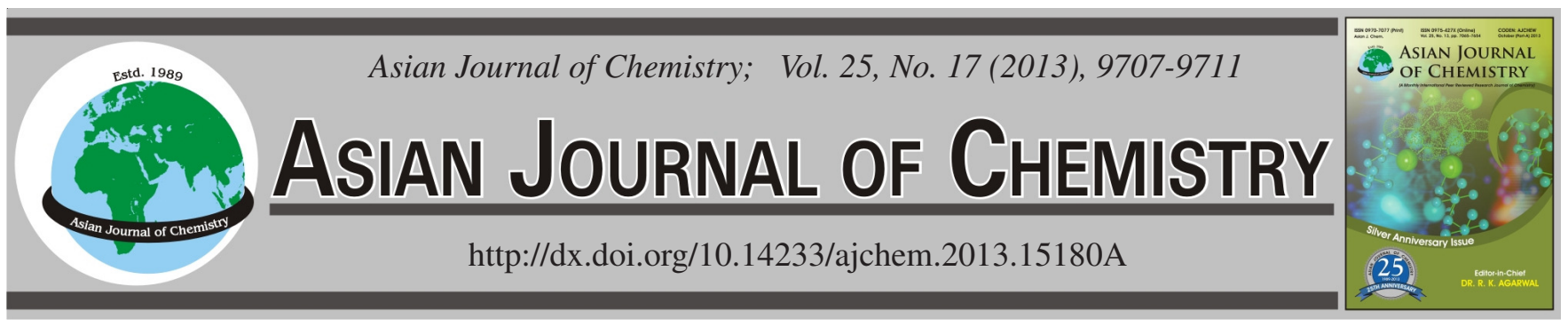

\title{
Assessment of Poisonous Metal Concentration in Preferred Tissues of Two Dissimilar Classes of Ruminants in Punjab, Pakistan
}

\begin{abstract}
Muhammad Ayub ${ }^{1}$, Muhammad Zuber ${ }^{2}$, Muhammad Yousaf $^{1}$, Shahid Hussain Arshad $^{3}$, Syed Hammad Raza ${ }^{4}$, Zafar Iqbal Khan ${ }^{5, *}$, Kafeel Ahmed ${ }^{5}$, Zahara Bibi ${ }^{5}$ and Muhammad Saleem Akhtar ${ }^{6}$
\end{abstract}

\author{
${ }^{1}$ Department of Chemistry, Government College University, Faisalabad 38040, Pakistan \\ ${ }^{2}$ Department of Applied Chemistry, Government College University, Faisalabad 38040, Pakistan \\ ${ }^{3}$ Department of Civil Engineering, Iqra National University, Peshawar 25000, Pakistan \\ ${ }^{4}$ Department of Botany, Government College University, Faisalabad 38040, Pakistan \\ ${ }^{5}$ Department of Biological Sciences, University of Sargodha, 40100, Pakistan \\ ${ }^{6}$ Faculty of Veterinary Sciences, Bahauddin Zakria,University, Multan, Pakistan
}

*Corresponding author: E-mail: zikhan11@gmail.com

\begin{abstract}
Heavy metals are mostly considered toxic for animals as well as for humans. The purpose of this study was to determine the concentrations of copper in various organs (livers, kidneys, lungs, ribs, cerebrum, blood-serum, bones and hair) of cattle and buffaloes of both sexes with different ages, in two districts of Punjab. A total of 480 samples were collected and lead concentration was estimated by using atomic absorption spectrophotometer. Analysis of variance of data for lead concentration mostly in cerebrum, blood-serum and lungs showed significant effect $(p<0.05)$ of the locality and age of all classes of animals. Its level was also significant $(p<0.05)$ in the liver, kidney, ribs, bones and hair of animals of both sexes but reverse was true for lungs of the female cows in which Pb concentration was non-significant. It was found that the concentrations depend upon the sampling organs, animal species and locality of animals. The concentrations of lead in the liver and kidney $(7.48 \pm 0.33,8.86 \pm 0.56)$ and $(8.63 \pm 0.86,8.25 \pm 0.99)$ in the male cows of district Jhang and Toba, whereas $(7.72$ $\pm 0.41,7.04 \pm 0.62)$ and $(8.12 \pm 0.68,6.86 \pm 0.48)$ in the female cows of district Jhang and Toba, were found to be higher. Similarly its concentrations in the liver and kidney $(7.89 \pm 0.51,9.48 \pm 0.55)$ and $(8.41 \pm 0.94,6.44 \pm 0.69)$ in the male buffaloes of district Jhang and Toba, respectively $(6.32 \pm 0.49,9.08 \pm 0.45)$ and $(8.49 \pm 0.95,5.31 \pm 0.65) \mathrm{mg} \mathrm{kg}^{-1}$ in the female buffaloes of district Jhang and Toba and were found to be higher as compared to the critical values. In forage of district Toba, the mean \pm standard error (SE) of lead concentration $\left(22.86 \pm 0.31 \mathrm{mg} \mathrm{kg}^{-1}\right)$ was higher, while at Jhang, its concentration $(22.18 \pm 0.45)$ was lower as compared to the corresponding concentration $\left(22.72 \pm 0.27 \mathrm{mg} \mathrm{kg}^{-1}\right)$ of control farms, respectively. In soil of district Jhang and Toba, Pb concentration $(2.84 \pm 0.11$ and $3.62 \pm 0.20 \mathrm{mg}$ $\left.\mathrm{kg}^{-1}\right)$ was found to be higher as compared to that of control farm $\left(1.82 \pm 0.20 \mathrm{mg} \mathrm{kg}^{-1}\right)$. So one should be careful in consuming liver and kidney of cows and buffaloes as the accumulation of lead in these organs is found to be very high beyond the safe limit. It is essential to use supplementation of mineral mixture to soil, forages and animals in appropriate proportion (tailored mixture) to decrease mineral toxicity and also the reproductive potential, fertility and growth rate of grazing animals can be increased.
\end{abstract}

Key Words: Tissues, Blood-serum, Buffaloes, Cattle, Plant, Soil, Animal, Mineral.

\section{INTRODUCTION}

Agricultural economy of Pakistan also depends upon the healthy cows and buffaloes as they produce milk, meat and fat for human and most of the animals are producing below their genetic potential possibly due to mineral imbalances. The animals, graze in contaminated area (meadows) have greatest chance of exposure to the toxic metals than those which are away from the source of these pollutants ${ }^{1}$. Toxic elements mean which have no advantage but give severe toxicological symptoms even at low concentration. In those areas where many industries are established, the accumulation of toxicities of heavy metals occur, which make a cause of polluted environment because these heavy metals cannot be degraded. They enter into animal tissues after passing through the food material $^{2}$. The most common heavy metals such as lead, mercury and cadmium, have toxic effect on animals as well as human being. As a result, the rate of meat and milk production decreased and contaminated products are highly increased ${ }^{3-6}$. The heavy metals are mostly accumulated in kidneys, small intestine and livers of male cattle. The heavy metal which acts as a neurotoxin and metabolic poison, inactivate the 
cellular components as well as many significant enzymes ${ }^{8}$. Environmental pollution is the major cause of the heavy metal contamination. Mercury, lead, cadmium, arsenic, chromium, copper and zinc etc. are included in heavy metals. The major biochemical effect of lead is very dangerous, because it causes hematological damage by interfering heme synthesis. Actually it inhibits some important enzymes which are essential for heme synthesis in animals when blood lead level increased upto $0.8 \mathrm{ppm}$, it causes anemia, due to hemoglobin deficiency. Lead interfere electron transport in cell mitochondria, if phosphate is present. Lead inactivates the enzyme by reacting with it's SH group (active site) and lead accumulation causes bone abnormalities in animals, because it replace calcium and it is subsequently remobilized along with phosphates from the bones and give insidious effects, when transported to soft tissues. Lead poisoning can be cured by using chelating agents' technique. Plant species absorb a fraction of mineral from soils 9 .

Lead is a heavy metal which is highly toxic. If the environment is polluted by lead, it creates serious problem for grazing animals and human being. Liver, kidney, lungs, ribs, cerebrum, blood serum, bones and hair of animals absorb lead from polluted environment and when its level increases, it becomes toxic for human being ${ }^{10}$. Lead has highly adverse effect not only on children but also on adults' growth and health, in which children absorb greater amount of lead and show toxicity even at lower level ${ }^{11}$. Lead accumulation may causes many chronic diseases like cancer, central nervous system is badly affected, nephro-toxicity and cardio vascular disease ${ }^{12,13}$. Toxic effect of lead is associated with age, sex, frequency of intake, percentage of retention, solubility, oxidation state of metal and mechanism as well as efficiency of excretion. Lead can be absorbed by breathing and cause to destroy emotional stability, decrease hearing ability and cause hyper-activity ${ }^{14}$. Lead is originated in atmosphere as pollution from many industrial sources for example, the leakage of gasoline. More, the traffic in big cities results in more polluted streets and houses near $\operatorname{road}^{15}$. In this way, air, rain and under ground water and soil can contaminate foods of the living organism. Lead level is elevated in various organs of ruminants of different areas as compared to controlled groups due to lead pollution, abiotic and biotic ecosystem ${ }^{16}$. Sources of lead environmental pollutions are paints, batteries, gun powder, engine oil, gasoline, soldering rods, chemical fertilizers and fungicide, etc. ${ }^{17}$. Lead concentration is found to be increase in blood and various organs of animals that are grazing near lead polluted areas. Osteoporosis is resulted due to lead affinity with bones, liver and kidney of ruminants. It accumulation also causes anemia by disturbing metabolism of iron and manganese ${ }^{18}$.

The aim of this study was to assess the $\mathrm{Pb}$ level in blood and various indicating organs like liver, kidney, lungs, ribs, cerebrum, blood-serum, bones and hair of the cows and buffalos at different areas of Punjab in Pakistan, so that lead accumulation can be prevented to increase reproductive potential and growth of ruminates at two districts of Punjab, the province of Pakistan. This study will help us not only in evaluating the toxicological effect of $\mathrm{Pb}$ but also examine its adverse effect on fertility and health of the animals. By having the knowledge of mineral status of animals, the various measures should be done to improve the mineral nutrition by supplementation with mixture minerals to the animals and thus increasing the reproductive potential.

\section{EXPERIMENTAL}

Various samples of soil, fodder and animal tissues were collected from fields of Jhang, Toba and two controlled farms (livestock farm of Rakh Khairewala, district Layyah and Ever Green livestock farm district Jhang). Sugar cane tops, turnips, local weeds and grasses etc. are fodder which is frequently grazed by cattle and buffaloes. Comparing of lead levels in plasma and different tissues of selected animals with those of critical levels, tells us the $\mathrm{Pb}$ concentration above which specific signs of toxicity may occur. Samples of fodder were collected from the same areas where samples of the soil were collected. All of the samples were washed, dried and ground carefully to take into powder form for mineral analysis. The 480 samples of various tissues (blood-serum, cerebrum, liver, kidney, lungs, ribs, bones and hair) from selected cattle and buffaloes of both sexes ( 30 cows and 30 buffaloes which have age in the range of 2 to 13 years) were collected from controlled farms and different fields at two districts, viz., Jhang and Toba Tek Singh, Punjab, Pakistan. These dried but pure samples were passed through wet digestion.

Wet digestion: For this purpose, $2 \mathrm{~mL}$ of the bloodserum and $2 \mathrm{~g}$ of each of the tissue samples of selected animals were taken in a conical flask then add $20 \mathrm{~mL}$ of acid mixture $\left(\mathrm{H}_{2} \mathrm{SO}_{4}: \mathrm{HNO}_{3}: \mathrm{HClO}_{4}\right)$ with the ratio of 1:5:2. By using hot plate, the solution was heated properly and finally the whitish fumes appear, which was the sign of fully dissolved organic matter and $c a .3 \mathrm{~mL}$ of the remaining transparent solution was observed in flask. Then made $60 \mathrm{~mL}$ of solution by using double distilled water and preserved in labelled bottles after filtration, which was used to assess the concentration of lead mineral. By using standard solution of lead element, calculated the lead concentration in each of the given sample ${ }^{19}$. Finally lead metal was analyzed in all the samples of soil, forage and animal tissues by using atomic absorption spectrophotometer, reported by Anwar et $a l^{20}$. The results evaluated from the specified indicators were passed through the general linear model Statistica, powerful statistical software. The variation among the mean values was graded by applying Duncan's new multiple range test ${ }^{21}$.

\section{RESULTS AND DISCUSSION}

In present study, the concentrations of lead obtained in animal tissues, blood-serum, forages and soil were compared with those of controlled farms and also with the reference values already present in literature to assess the toxic effect of lead. The results pertaining to concentration of lead in different organs of cows and buffaloes (liver, kidneys, ribs, cerebrum, blood- serum lungs, bones and hair) are shown and their concentrations are presented as mean \pm SE values and augmented with bar charts and tables. Analysis of variance of data for $\mathrm{Pb}$ concentration in liver, cerebrum, blood-serum, lungs and bones showed significant result $(p<0.05)$ of the district and age of the male cows, but reverse was true for kidney, ribs and hair, in which $\mathrm{Pb}$ concentration was non- 
significant $(p>0.05)$ (Table-1). The mean \pm SE lead concentrations $(7.48 \pm 0.33,8.86 \pm 0.56,4.34 \pm 0.34,5.54 \pm 0.27$, $\mathrm{mg} \mathrm{kg}^{-1}$ and $\left.3.15 \pm 0.36 \mathrm{mg} \mathrm{L}^{-1}\right)$ and its concentrations $(8.63 \pm$ $0.86,8.25 \pm 0.99,4.48 \pm 0.53,6.8 \pm 0.48 \mathrm{mg} \mathrm{kg}^{-1}$ and $6.61 \pm 0.73$ $\mathrm{mg} \mathrm{L}^{-1}$ ) in liver, kidney, ribs, cerebrum and blood-serum of male cows of both districts, Jhang and Toba, were higher as compared to the corresponding concentrations $(6.71 \pm 0.20$, $7.03 \pm 0.57,3.54 \pm 0.26,3.61 \pm 0.28 \mathrm{mg} \mathrm{kg}^{-1}$ and $4.05 \pm 0.16$ $\mathrm{mg} \mathrm{L}^{-1}$ ) of control groups, respectively (Fig. 1a).

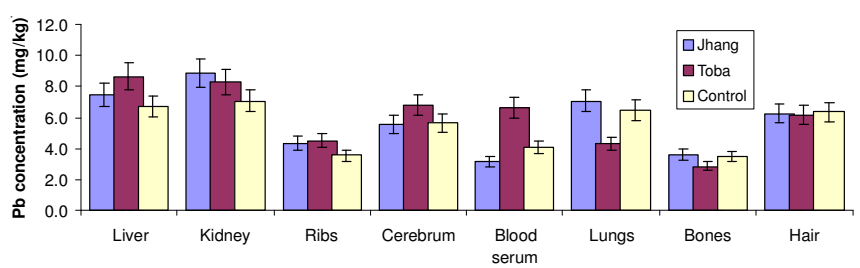

Fig. 1. (a) Fluctuation in levels of lead in liver, kidney, ribs, cerebrum, blood-serum, lungs, bones and hair of male cows

Analysis of variance of data for lead concentration in the liver, kidney, ribs, cerebrum, blood-serum, lungs, bones and hair showed significant $(p<0.05)$ result of the district and age of the female cows (Table-2). The mean \pm SE lead concentrations $(7.72 \pm 0.41,7.04 \pm 0.62,4.59 \pm 0.38,6.94 \pm 0.38$ and $3.0 \pm$ $0.34) \mathrm{mg} \mathrm{kg}^{-1}$ in the liver, kidney, ribs, cerebrum and bones of female cows in district Jhang were higher as compared to the corresponding concentrations $(7.7 \pm 0.49,6.75 \pm 0.92,3.93 \pm$ $0.37,5.53 \pm 0.35$ and $2.29 \pm 0.175) \mathrm{mg} \mathrm{kg}^{-1}$ of control groups and its concentrations $(8.12 \pm 0.68,6.86 \pm 0.483 .37 \pm 0.60$ and $5.97 \pm 0.46 \mathrm{mg} \mathrm{L}^{-1}$ ) in liver, kidney, bones and bloodserum, of female cows of Toba were higher as compared to the corresponding concentrations $(7.7 \pm 0.49,6.75 \pm 0.92$, $2.29 \pm 0.17$ and $\left.5.48 \pm 0.29 \mathrm{mg} \mathrm{L}^{-1}\right)$ of control groups, respectively (Fig. 1b).

Analysis of variance of data for lead concentration in liver, kidney, ribs, cerebrum, blood-serum and lungs, showed

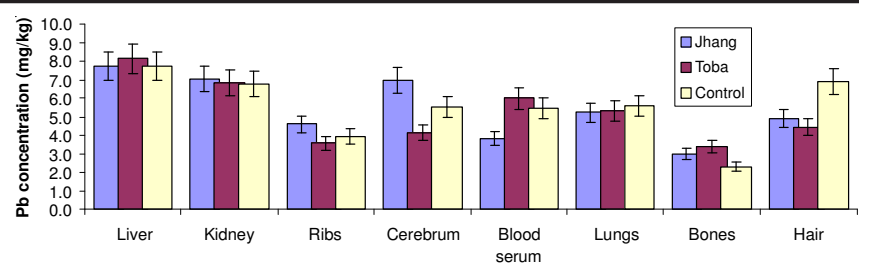

Fig. 1. (b) Fluctuation in levels of lead in liver, kidney, ribs, cerebrum, bloodserum, lungs, bones and hair of female cows

significant result $(p<0.05)$ of the district and age of the male buffaloes, but reverse was true for bones and hair, in which lead concentrations were non-significant $(p>0.05)$ (Table-3). The mean \pm SE lead concentrations $(9.48 \pm 0.55,4.57 \pm 0.37$, $4.66 \pm 0.29$ and $\left.4.11 \pm 0.25 \mathrm{mg} \mathrm{L}^{-1}\right)$ in kidney, ribs, bones and blood-serum of male buffalos in district Jhang were higher as compared to the corresponding concentrations $(8.25 \pm 0.2$, $4.11 \pm 0.1,4.46 \pm 0.05$ and $\left.3.99 \pm 0.2 \mathrm{mg} \mathrm{L}^{-1}\right)$ of control groups and its concentrations $\left(7.81 \pm 0.68 \mathrm{mg} \mathrm{L}^{-1}\right)$ in blood-serum, of male buffalos of Toba was higher as compared to the corresponding concentrations $\left(3.99 \pm 0.2 \mathrm{mg} \mathrm{L}^{-1}\right)$ of control groups, respectively (Fig. 2a).

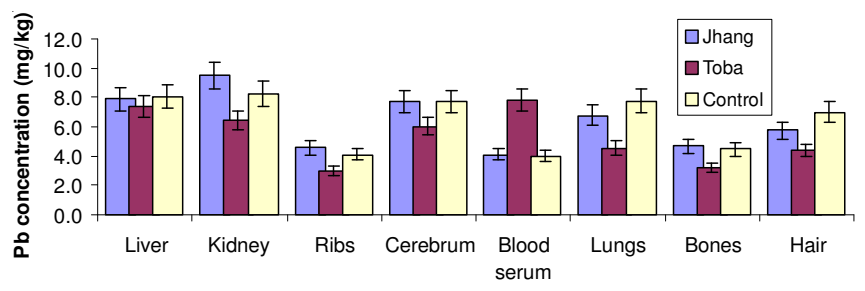

Fig. 2. (a) Fluctuation in levels of lead in liver, kidney, ribs, cerebrum, blood-serum, lungs, bones and hair of male buffaloes

Analysis of variance of data for lead concentration in the liver, kidney, ribs, cerebrum, blood-serum, lungs, bones and hair showed significant result $(p<0.05)$ of the district and age of the female buffaloes (Table- 4 ). The mean \pm SE lead concentrations $(6.32 \pm 0.49,9.08 \pm 0.45,4.53 \pm 0.38,7.23 \pm 0.37$,

\begin{tabular}{|c|c|c|c|c|c|c|c|c|c|}
\hline \multirow{4}{*}{$\begin{array}{l}\text { Source of } \\
\text { variation } \\
\text { S.O.V }\end{array}$} & \multicolumn{8}{|c|}{$\begin{array}{c}\text { TABLE-1 } \\
\text { ANALYSIS OF VARIANCE OF DATA FOR LEAD CONCENTRATION IN VARIOUS ORGANS } \\
\text { OF MALE COWS OF DIFFERENT AGE GROUPS AT TWO DISTRICTS OF PUNJAB }\end{array}$} & \\
\hline & \multirow{3}{*}{$\begin{array}{l}\text { Degree of } \\
\text { freedom } \\
\quad \text { df }\end{array}$} & \multicolumn{8}{|c|}{ Mean square } \\
\hline & & \multicolumn{8}{|c|}{ Male cows } \\
\hline & & Liver & Kidney & Ribs & Cerebrum & Blood-serum & Lungs & Bones & Hair \\
\hline Districts & 1 & $11.868^{*}$ & $3.861^{\mathrm{ns}}$ & $0.1764^{\mathrm{ns}}$ & $14.203^{*}$ & $107.57 *$ & $68.421 *$ & $4.9136^{*}$ & $0.085^{\mathrm{ns}}$ \\
\hline Error & 4 & 0.2487 & 0.914 & 0.4737 & 0.7662 & 1.067 & 0.6283 & 0.3821 & 0.29 \\
\hline Ages & 5 & $15.441 *$ & $27.974 *$ & $4.3069 *$ & $1.4539 *$ & $5.893^{*}$ & $5.803 *$ & $0.9513^{*}$ & $12.969 *$ \\
\hline DxA & 5 & $8.1479 *$ & $8.4^{*}$ & $6.1432 *$ & $5.4277 *$ & $9.964 *$ & $8.8539 *$ & $1.8055^{*}$ & $19.355^{*}$ \\
\hline Error & 20 & 0.5329 & 0.535 & 0.3122 & 0.4482 & 0.854 & 0.7148 & 0.3476 & 0.632 \\
\hline
\end{tabular}

\begin{tabular}{|c|c|c|c|c|c|c|c|c|c|}
\hline \multirow{4}{*}{$\begin{array}{l}\text { Source of } \\
\text { variation } \\
\text { S.O.V }\end{array}$} & \multicolumn{8}{|c|}{$\begin{array}{c}\text { TABLE-2 } \\
\text { ANALYSIS OF VARIANCE OF DATA FOR LEAD CONCENTRATION IN VARIOUS ORGANS OF } \\
\text { FEMALE COWS OF DIFFERENT AGE GROUPS AT TWO DISTRICTS OF PUNJAB }\end{array}$} & \\
\hline & \multirow{3}{*}{$\begin{array}{l}\text { Degree of } \\
\text { freedom } \\
\quad \text { df }\end{array}$} & \multicolumn{8}{|c|}{ Mean square } \\
\hline & & \multicolumn{8}{|c|}{ Female cows } \\
\hline & & Liver & Kidney & Ribs & Cerebrum & Blood-serum & Lungs & Bones & Hair \\
\hline Districts & 1 & $1.4^{\mathrm{ns}}$ & $0.3025^{\mathrm{ns}}$ & $9.579 *$ & $69.723 *$ & $41.753^{*}$ & $0.6225^{\mathrm{ns}}$ & $1.2432^{\mathrm{ns}}$ & $2.1365^{\mathrm{ns}}$ \\
\hline Ages & 5 & $8.5296^{\mathrm{ns}}$ & $8.7343 *$ & $4.8465 *$ & $2.2289 *$ & $4.1024 *$ & $7.9845^{*}$ & $4.124 *$ & $6.6132 *$ \\
\hline DxA & 5 & $7.9216^{*}$ & $7.0658 *$ & $2.8154 *$ & $9.2445^{*}$ & $3.844 *$ & $7.2418^{*}$ & $6.0053^{*}$ & $10.814 *$ \\
\hline Error & 20 & 0.5761 & 0.5816 & 0.7662 & 0.8111 & 0.5072 & 0.3497 & 0.5658 & 0.3628 \\
\hline
\end{tabular}


TABLE-3

ANALYSIS OF VARIANCE OF DATA FOR LEAD CONCENTRATION IN VARIOUS ORGANS OF MALE BUFFALOES OF DIFFERENT AGE GROUPS AT TWO DISTRICTS OF PUNJAB

\begin{tabular}{|c|c|c|c|c|c|c|c|c|c|}
\hline \multirow{3}{*}{$\begin{array}{c}\text { Source of } \\
\text { variation } \\
\text { S.O.V }\end{array}$} & \multirow{3}{*}{$\begin{array}{c}\text { Degree of } \\
\text { freedom } \\
\text { df }\end{array}$} & \multicolumn{8}{|c|}{ Mean square } \\
\hline & & \multicolumn{8}{|c|}{ Male buffaloes } \\
\hline & & Liver & Kidney & Ribs & Cerebrum & Blood-serum & Lungs & Bones & Hair \\
\hline Districts & 1 & $2.035^{\mathrm{ns}}$ & $83.357 *$ & $22.42 *$ & $25.164^{*}$ & $123.1^{*}$ & $45.226^{*}$ & $19.345^{*}$ & $16.443^{\mathrm{n}}$ \\
\hline Error & 4 & 0.945 & 1.326 & 0.4298 & 0.7047 & 0.848 & 1.109 & 0.3108 & 2.5878 \\
\hline Ages & 5 & $18.91 *$ & $12.825^{*}$ & $9.3157 *$ & $6.1511^{*}$ & $7.321 *$ & $4.3579 *$ & $2.5066^{*}$ & $9.4576 *$ \\
\hline DxA & 5 & $12.256^{*}$ & $8.627 *$ & $3.443^{*}$ & $5.9846^{*}$ & $5.8202 *$ & $5.4281^{*}$ & $6.336^{*}$ & $9.5826 *$ \\
\hline Error & 20 & 0.718 & 0.326 & 0.3404 & 0.4354 & 0.563 & 0.6639 & 0.3621 & 0.4632 \\
\hline
\end{tabular}

TABLE-4

ANALYSIS OF VARIANCE OF DATA FOR LEAD CONCENTRATION IN VARIOUS ORGANS OF FEMALE BUFFALOES OF DIFFERENT AGE GROUPS AT TWO DISTRICTS OF PUNJAB

\begin{tabular}{|c|c|c|c|c|c|c|c|c|c|}
\hline \multirow{3}{*}{$\begin{array}{c}\text { Source of } \\
\text { variation } \\
\text { S.O.V }\end{array}$} & \multirow{3}{*}{$\begin{array}{l}\text { Degree of } \\
\text { freedom } \\
\text { df }\end{array}$} & \multicolumn{8}{|c|}{ Mean square } \\
\hline & & \multicolumn{8}{|c|}{ Female buffaloes } \\
\hline & & Liver & Kidney & Ribs & Cerebrum & Blood-serum & Lungs & Bones & Hair \\
\hline Districts & 1 & $42.51 *$ & $128.07 *$ & $1.174^{\mathrm{ns}}$ & $31.925^{*}$ & $149.28 *$ & $90.599 *$ & $2.5483^{\text {ns }}$ & $37.685^{*}$ \\
\hline Error & 4 & 0.276 & 1.397 & 0.7029 & 0.9648 & 0.836 & 2.078 & 0.2608 & 0.3172 \\
\hline Ages & 5 & $22.506^{*}$ & $5.855^{*}$ & $6.1945^{*}$ & $0.6229 *$ & $4.57 *$ & $5.232 *$ & $6.1179 *$ & $7.8895^{\mathrm{ns}}$ \\
\hline DxA & 5 & $10.38 *$ & $10.866^{*}$ & $4.4258^{*}$ & $1.4095^{*}$ & $10.473^{*}$ & $5.653 *$ & $4.4033^{*}$ & $1.2813^{*}$ \\
\hline Error & 20 & 0.514 & 0.325 & 0.44 & 0.4397 & 0.625 & 0.564 & 0.4425 & 0.5105 \\
\hline
\end{tabular}

$4.74 \pm 0.26$ and $5.86 \pm 0.40 \mathrm{mg} \mathrm{kg}^{-1}$ ) in the liver, kidney, ribs, lungs, bones and hair of female buffalos in district Jhang were higher as compared to the corresponding concentrations $(5.78$ $\pm 0.8,5.9 \pm 0.9,2.0 \pm 0.2,3.96 \pm 0.4,3.77 \pm 0.3$ and $4.74 \pm$ $\left.0.40 \mathrm{mg} \mathrm{kg}^{-1}\right)$ of control groups and its concentrations $(8.49 \pm$ $0.9,4.13 \pm 0.53,4.06 \pm 0.5,4.21 \pm 0.5$ and $\left.8.18 \pm 0.6 \mathrm{mg} \mathrm{L}^{-1}\right)$ in blood-serum, of female buffalos of Toba was higher as compared to the corresponding concentrations $(5.78 \pm 0.5,2.0$ $\pm 0.2,3.96 \pm 0.4,3.77 \pm 0.3$ and $\left.7.96 \pm 0.8 \mathrm{mg} \mathrm{L}^{-1}\right)$ of control groups, respectively (Fig. 2b).

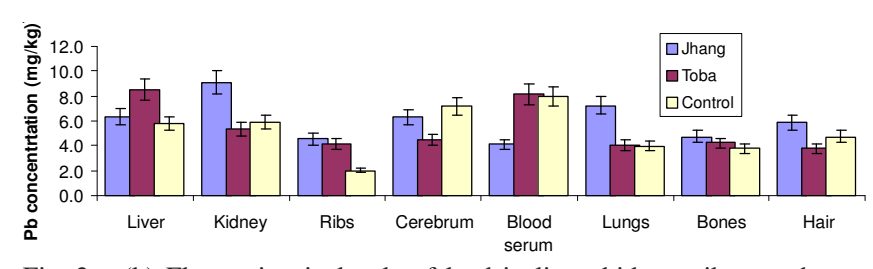

Fig. 2. (b) Fluctuation in levels of lead in liver, kidney, ribs, cerebrum, blood-serum, lungs, bones and hair of female buffaloes

The mean \pm SE lead levels for the fodder samples from the fields of Jhang and Toba were $22.18 \pm 0.45$ and $22.86 \pm$ $0.31 \mathrm{mg} \mathrm{kg}^{-1}$, respectively and for these samples from the control farm were $22.72 \pm 0.27 \mathrm{mg} \mathrm{kg}^{-1}$ lead concentration in fodders was slightly lower at district Jhang and slightly higher at Toba as compared to those of control farm, respectively (Fig. 3a).

The mean \pm SE lead levels for the soil samples from the fields of Jhang and Toba were $2.84 \pm 0.11$ and $3.62 \pm 0.20 \mathrm{mg}$ $\mathrm{kg}^{-1}$, respectively and for the soil samples from the control farm were $1.82 \pm 0.20 \mathrm{mg} \mathrm{kg}^{-1}$. Lead concentration was higher in soil of both districts Jhang and Toba as compared to that of control farm (Fig. 3b).

Lead concentration was non-significant in liver and hair of male buffaloes and female cows, while it was significant in

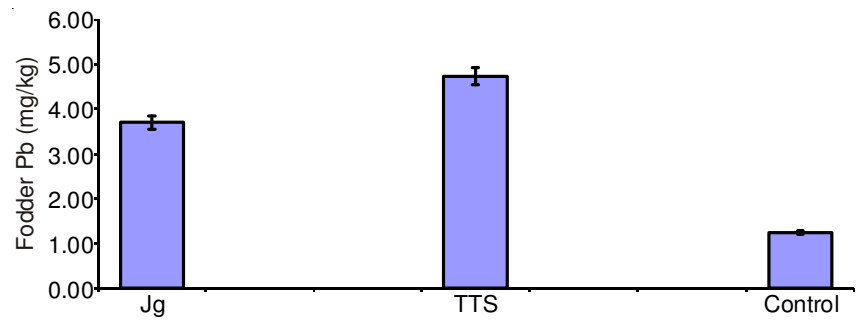

Fig. 3. (a) Mean \pm SE lead levels in the fodders of Jhang, Toba and controlled farms

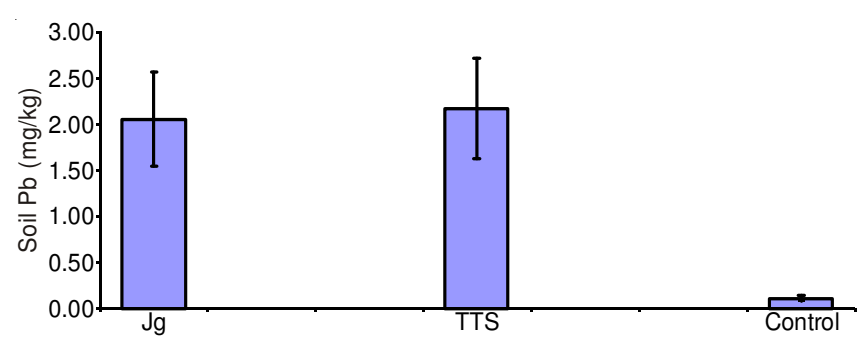

Fig. 3. (b) Mean \pm SE lead levels in the soil of Jhang, Toba and controlled farms

blood-serum and other organs of all animals at both districts of Punjab and its concentration was lower in blood-serum of all cows and buffaloes at Jhang, while reverse was true for those of Toba as compared to controlled groups, similarly higher level of lead was found in blood-serum of cows by Skalika et al. ${ }^{22}$ Higher levels of lead were found in liver and kidney as compared to other organs of all animals of both districts. The higher metal accumulation in the liver of dairy cattle was related to higher hepatic metabolism, which was associated with milk production and it was not related to high dietary intake. Lopez-Alonso ${ }^{23}$ reported that forage and soil $\mathrm{Cu}$ levels were higher in the fields of both districts than that of farms, which was similar to the reports of Tifani et al. ${ }^{24}$. Results showed that the concentration of lead exceeded the 
recommended value. The concentrations in the present study were slightly higher than that recorded by Abou-Arab ${ }^{25}$.

Finally, it can be reported that the highest levels of lead were estimated in liver and kidney of cattle due higher concentration in forage and soil. Maldonado et al. ${ }^{26}$ reported that a higher level of lead in these organs during animal lactation was due to its gastrointestinal absorption, redistribution and mobilization. ANZFA ${ }^{27}$ studied the lower level of lead in liver and kidney of cattle than that of the permissible level. The slight difference of lead in various groups of cows and buffaloes was due to the variation of soil chemistry, different digestibility of lead from their food, difference in nature of forages and fluctuation in the climatic conditions. Swarup et al. ${ }^{28}$ studied that lead was stored in various parts of the animal body particularly in liver, kidney, brain and bones after passing through intestine and blood-serum.

\section{Conclusion}

It was concluded that the minerals are distributed in various tissues of ruminants after absorbing through gastrointestinal tract of these animals. From results, we studied that toxic heavy metals like lead concentrations were found to be higher in liver and kidney of cows and buffaloes of both sexes than those of other organs, due to the availability of toxic minerals in water, soil and vegetations beyond the safe limit. Thus liver and kidney are the main indicating organs of ruminants which can highly accumulate the toxic elements. Lead accumulation may cause a chronic poisoning. If lead poisoning or toxicity becomes maximum in cows and buffaloes, they may be expired. It is essential to use supplementation of mineral mixture to soil, forages and animals in appropriate proportion (tailored mixture) to decrease mineral toxicity and in this way reproductive potential, fertility or growth rate of animals can be increased everywhere.

\section{REFERENCES}

1. Y. Akar and H. Yildiz, Turk. J. Vet. Anim. Sci., 29, 1157 (2005).

2. B.D. Baykov, M.P. Stoyanov and M.L. Gugova, Toxicol. Environ. Chem., 54, 155 (1996).
3. I. Maracek, L. Lazar and I. Dietzova, Vet. Medicina., 42, 283 (1998).

4. P. Massanyi, P. Nad, R. Toman and J. Kovacik, Aust. J. Agric. Res., 52, 56 (2001).

5. A.R. Tairova, Zootechnics., 9, 27 (2001).

6. L. Jarup, Br. Med. Bull., 68, 167 (2003).

7. D. Horky, J. Illek and A. Pechova, Vet. Med., 43, 331 (1998).

8. W.P. Cunningham and B.W. Saigo, Environmental Science a Global Concern, WMC Brown Publisher, New York, edn. 4, p. 389 (1997).

9. S. Tokalioglu, S. Kartal and A.A. Gunis, Int. J. Environ. Anal. Chem., 80, 210 (2000).

10. R.V. Baht and G.G. Moy, Technol. Report, 50, 132 (1997).

11. ATSDR, Agency for Toxic Substances and Disease Registry. Toxicological profile for COPPER. US Department of Health and Human Services Atlanta, GA, USA (1999).

12. C.H. Pitot and P.Y. Dragan, Chemical carcinogenesis. In: Casarett and Doull's Toxicology, International Edition, McGraw Hill, New York, edn. 5, pp. 201-260 (1996).

13. P.B. Ryan, N. Huet and D.L. Maclntosh, Environ. Health Perspect., 108, 731 (2000).

14. R.A. Goyer, Environ. Health Perspect., 104, 1050 (1996).

15. M.L. Durands and S.R. Aragon, Environ. Sci. Technol., 16, 20 (1982).

16. N.I. Ward and J.M. Savage, Sci. Total Environ., 146, 185 (1994).

17. P.S. Mlay and Y.O. Mgumia, Livest. Res. Rural Dev., 20, 4 (2008).

18. T. Zadnik, Int. J. Environ. Pollut., 31, 34 (2007).

19. H. Kamada, H.K. Nishimura, P. Krongyuti, P. Sukkasame, N. Phoengpong and S. Intramanee, Asian Aust. J. Anim. Sci., 13, 757 (2000).

20. F. Anwar, T.G. Kazi, R. Saleem and M.I. Bhanger, Grasasy Aceites, 55, 160 (2004).

21. D.P. Duncan, Biometric. J., 11, 1 (1955).

22. M. Skalicka, B. Korenekekova and P. Nad, Trace Elem. Electrolytes, 19, 53 (2002).

23. M. Lopez-Alonoso, F.M. Prieto, M. Miranda, C. Castillo and J. Hernandez, Vet. Hum. Toxicol., 45, 128 (2003).

24. M.E. Tifani, L.R. Mccdowell, G.A.O' Connor, F.G. Martin, N.S. Wilkinson, S.S. Percival and P. Rabiansky, J. Anim. Sci., 80, 260 (2002).

25. A.A.K. Abou-Arab, Food Chem. Toxicol., 39, 593 (2001).

26. M. Maldonado-Vega, J. Cerbon-Solorzano, A. Albores-Medina, C. Hernandez-Luna and J. Calderon-Salinas, Hum. Exp. Toxicol., 15, 872 (1996).

27. ANZFA (Australia New Zealand Food Authority), Wellington NZ 6036 May (2001).

28. D. Swarup, R.C. Patra, R. Naresh, P. Kumar and P. Shekhar, Sci. Total Environ., 15, 67 (2005). 